\title{
Evaluační strategie středisek ekologické výchovy
}

\section{Jan Činčera}

\author{
Envigogika 2008/III/ 2 - Recenzované články/ Reviewed Papers
}

Publikováno/Published 22. 12. 2008

\section{DOI: http://dx.doi.org/10.14712/18023061.29}

\begin{abstract}
Abstrakt:
Článek prezentuje výsledky kvalitativního výzkumu evaluačních strategií středisek ekologické výchovy $v$ České republice. Identifikuje čtyři základní evaluační strategie a související proměnné. Pro první typ jsou charakteristické programy, jejichž hodnocení závisí hlavně na zkušenosti lektora. Využívají nestrukturovaná pozorování a naopak nepoužívají výzkumné metody. $V$ druhém typu jsou zahrnuta centra, jejichž metodou hodnocení jsou různé typy strukturovaných pozorování a hodnocení provádějí většinou kolegové lektorů. Pro treté typ je příznačné hodnocení na základě chování studentů během programu. Takto orientovaná centra se ve svých programech orientují na studenta, poskytují mu možnost sebevyjádření. Čtvrtý typ center používá takové metody výzkumu, jež jsou založeny na různých způsobech sběr a hodnocení dat o znalostech, postojích, dovednostech a chování studentů. Protože s tímto př́stupem nemají dostatek zkušeností, hledají externí evaluátory z univerzit nebo jiných organizací.
\end{abstract}

\section{Klíčová slova:}

$\mathrm{XXXX}$

\section{Abstract:}

The article presents results of qualitative research focused on evaluation strategies of centres for environmental education in the Czech Republic. It identifies four main evaluation strategies and associated variables. Its main finding is identification of four main evaluation strategies based on differences in data collection processes and whether the evaluation is undertaken internally or externally: the first type characterizes centres that rely mainly on teachers' experience. They are dependent on teachers' unstructured observations and do not use further research methods. The second type is centres' use of various kinds of structured observations, the observers are usually colleagues or the teacher. The third type consists of centres whose teachers evaluate their programs on the basis of students' behavior during the program. They usually use some form of studentoriented teaching that gives students an opportunity for self-expression. The fourth type tries to exploit research methods based on different methods for collecting data about knowledge, attitudes, skills and behavior of students. Because of lack of experience, they seek external evaluators from universities or other organizations.

\section{Key words:}

$x x x x$ 


\section{Úvod}

Evaluace je proces kritického ověřování programu. Zahrnuje sběr a analýzu informací o aktivitách a výstupech programu. (Duvall, Higgs \& Volske, 2007) Evaluace je forma zpětné vazby, na jejímž základě mohou realizátoři programu rozhodovat o dalším vývoji a úpravách programu a zvyšovat tak jeho efektivitu. Výsledky evaluace mohou být dále využívány pro prezentaci a propagaci nabízených programů či pro komunikaci realizujícího střediska se sponzory.

Klíčovou roli v oblasti environmentální výchovy v České republice hrají organizace, spolupracující v rámci Sítě středisek ekologické výchovy Pavučina (dále SSEV Pavučina). Střediska (dále také SEV) nabízejí velké množství ekologických výukových programů (EVP) pro školy, vedou volnočasové kroužky, připravují letní tábory, školí pedagogy a publikují rưzné metodické materiály.

Cílem článku je analyzovat, jakým způsobem přistupují střediska ekologické výchovy k evaluaci svých programů, resp. jaké evaluační strategie se v rámci SSEV Pavučina objevují. Článek vychází z výsledků kvalitativního výzkumu, realizovaného autorem v období červen-září 2008.

\section{Stav řešené problematiky}

Evaluace programů environmentální výchovy není v České republice dosud zcela obvyklá. Z výzkumu Jančaříkové (2007) vyplývá, že učitelé environmentální výchovu bud' nehodnotí a nebo hodnotí žáky za jejich výkony (formou testu nebo reflexe projektu), není ale uvedeno, zda případné výsledky využívají pro evaluaci vlastních programů. výchovy.

Určitého rozšírení dochází systémy kvalitativních standardů v oblasti environmentální

Prvním typem standardu je certifikát Škola udržitelného rozvoje, udělovaný Klubem ekologické výchovy. (Kvasničková, 2007) Systém se bohužel soustředuje především na to, zda škola v rámci environmentální výchovy realizuje určité typy aktivit (např. soutěže, přehlídky) a pomíjí stranou jak jejich kvalitu, tak i obsah environmentálního kurikula.

Jiný standard je realizován v rámci škol zapojených do mezinárodního programu Ekoškola. Školy, které splní kritéria stanovená programem, získají nárok na titul Ekoškola a symbolickou zelenou vlajku. Kritéria souvisí s ekologizací provozu školy a se zapojením žáků do celého procesu. (Tereza, 2008)

Od roku 2006 existuje v rámci SSEV Pavučina Pracovní skupina $k$ hodnocení kvality ekologických výukových programü. Výstupem je sada kvalitativních standardů EVP a nástroj pro jejich formativní evaluaci.

Obecné požadavky na kvalitní EVP jsou formulovány v Ekopedagogově osmeru (Máchal, Činčera, Daňková \& Broukal, 2008). Osmero nejprve definuje EVP a poté formuluje hlavní kvalitativní požadavky na program, které jsou dále navázány na př́slušný evaluační nástroj - Hodnotící tabulku pro EVP (dále jen Hodnotící tabulka - viz př́loha).

Hodnotící tabulka se používá jako nástroj pro záznam informací ze zúčastněného pozorování. Programy jsou vyhodnocovány pomocí třiceti tři kritérií uspořádaných do devíti obecných kategorií. $V$ rámci každého kritéria pozorovatel hodnotí program na škále 5-1, kde pět bodů znamená nejvyšší stupeň kvality a jeden nejnižší. Každý stupeň je pro jednotlivá kritéria popsaný pomocí slovního indikátoru.

Ve školním roce 2007-8 byla Hodnotící tabulka ověřována ve vybraných střediscích, když pozorovateli byli bud' zaměstnanci kanceláře SSEV Pavučina nebo pracovníci jednotlivých středisek. Hodnotící tabulka je od roku 2007 používána v rámci pravidelného 
Veletrhu EVP, na kterém jednotlivá střediska prezentují své programy a dostávají tak od pozorovatele zpětnou vazbu.

Součástí hodnocených kritérií jsou také požadavky na zabudovaný evaluační systém: „Je stanoven zpưsob, jakým bude hodnoceno dosažení cílư. Je zvolena vhodná metoda založená na pozorování, analýze práce, dotazování žákư apod. K hodnocení přispívá také pedagog nebo kolegové ze střediska. Výsledky hodnocení jsou zpracovány a použity pro další zkvalitňování EVP."

Využití Hodnotící tabulky je v současné době v rámci SSEV Pavučina diskutováno. Jednou z variant je i zavedení určitého typu certifikace programů. Současně není zřejmé, zda Hodnotící tabulka bude přijata všemi středisky, v jaké míře a zda sama o sobě umožňuje střediskům získat potřebnou zpětnou vazbu k efektivitě programů.

V dále prezentovaném výzkumu se pokusíme analyzovat, jakým způsobem střediska ekologické výchovy k evaluaci přistupují, zda používají i jiné metody než Hodnotící tabulku a jaký význam přisuzují evaluaci kvality svých programů.

\section{Cíle a vymezení výzkumu}

Cílem výzkumu bylo odpovědět na následující otázky:

- $\quad$ V jakém rozsahu se střediska ekologické výchovy v České republice zabývají evaluací svých programů? Jaký význam této evaluaci přisuzují?

- Jaké formy a metody evaluace střediska používají? Jaký je typický design evaluace?

- Existují mezi př́stupem středisek k evaluaci významnější rozdíly? Pokud ano, jak je mưžeme vymezit?

- Jaká je vědecká úroveň realizovaných evaluací? Používají střediska respektované metodiky pro rozbor kvantitativních či kvalitativních dat?

Prezentovaný výzkum je omezen na střediska působící v rámci SSEV Pavučina jako na reprezentanty nejdůležitější profesní organizace $v$ oboru environmentální výchovy. Výzkum byl realizován ve spolupráci s kanceláří SSEV Pavučina a jednotlivými středisky ekologické výchovy.

Zjištěné údaje odpovídají stavu v období červen-září 2008.

\section{Metodika výzkumu a charakteristika zkoumané populace}

SSEV Pavučina má v současné době 37 členských středisek a čtyři pozorovatele. Střediska působí ve všech krajích České republiky. Podle členských pravidel musí každé středisko realizovat nejméně sto hodin výukových či vzdělávacích akcí ročně a musí mít nejméně jednoho profesionálního pracovníka a zázemí. (Pavučina, 2008) Zkoumaná populace není zcela homogenní (střediska se liší velikostí, počtem zaměstnancừm, délkou existence i dalšími parametry), současně ale kritéria pro členství vytváří jasný rámec pro odlišení tohoto typu subjektů od jiných organizací.

Vzhledem k charakteru výzkumných otázek a malému počtu zkoumaných subjektů byla zvolena kvalitativní forma výzkumu. V rámci výzkumu byly použity následující metody sběru dat:

- Dotazníkové šetření mezi středisky.

- Rozhovory s pracovníky středisek (ústní i e-mailovou formou). 
- Analýza publikovaných a prezentovaných programů SEV.

- Analýza webovských prezentací SEV.

Proces zpracovávání dat byl kontinuální a cirkulární. Data z průběžně doručovaných dotazníků byla využita pro formulaci otázek pro navazující rozhovory a zpřesňující dotazy. Získané informace byly následně porovnány s analyzovanými programy. Nalezené nesoulady či opakující se vzorce byly ověřeny dalšími doplňujícími dotazy.

\section{Obr. č. 1. Proces sběru a zpracování dat.}

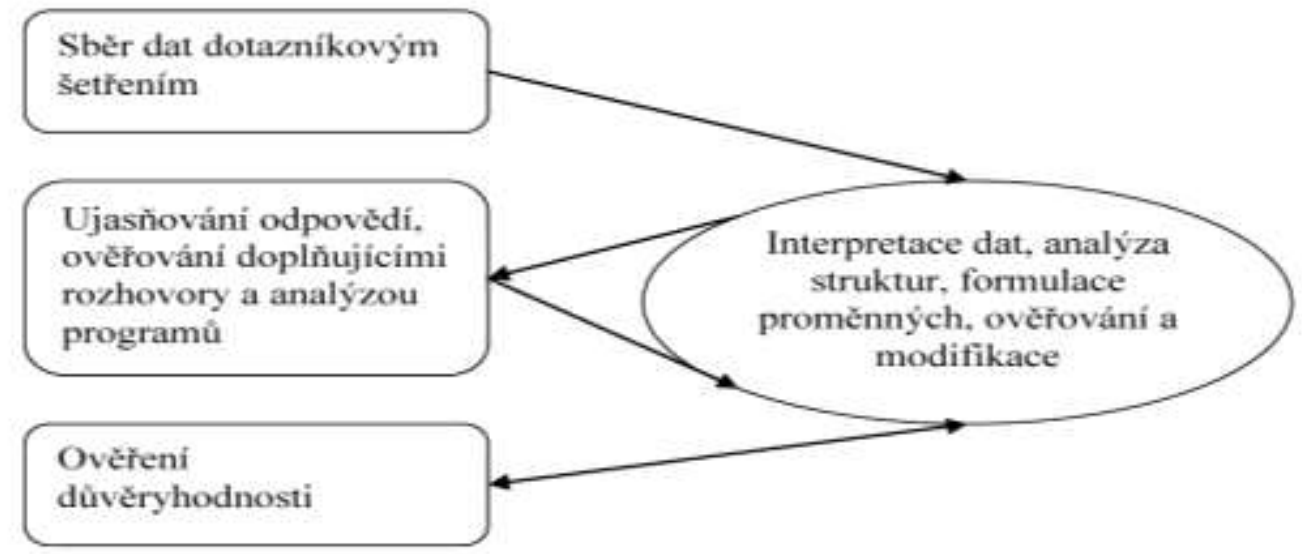

Dotazníkové šetření proběhlo v průběhu měsíců června až záŕí 2008. Jeho cílem bylo vytvořit popis základního profilu každého střediska z hlediska jeho př́istupu k evaluaci. Byla oslovena všechna členská střediska SSEV Pavučina. V případě nejasností v interpretaci některých výpovědí byli respondenti požádáni o zpřesnění odpovědi emailovou formou.

Získaná data byla využita pro vytvoření evaluačních profilů středisek. V procesu jejich analýzy se objevilo několik opakujících se vzorců, které umožnily prvotní kategorizaci středisek pomocí nově identifikovaných proměnných zdroje a autonomie.

V další fázi byly zkoumány doplňující proměnné, které jednotlivé kategorie charakterizovaly. Zdrojem byla volně dostupná data o střediscích, zejména publikované programy a webovské prezentace středisek. Nové kategorie byly dále ověřovány ústními rozhovory s pracovníky středisek, které probíhaly v období srpen - zář́í 2008.

$\checkmark$ poslední fázi jsme ověřovali důvěryhodnost (credibility) výsledků výzkumu. Každému z respondentů byla proto nabídnuta možnost připomínkovat předběžnou verzi prezentace výsledků. Této možnosti využila střediska Sluňákov a Křivoklátsko.

Celkem bylo do průzkumu zahrnuto devatenáct středisek: Alcedo (Vsetín), Čmelák (Liberec), Divizna (Liberec), Ekodomov (Praha), Chaloupky - Ostrůvek (Velké Meziříćí), Křivoklátsko (Křivoklát), Lipka (Brno) včetně poboček Jezírko (Brno) a Rychta Krásenko (Krásensko), Paleta (Pardubice), Podblanické ekocentrum ČSOP Vlašim (Vlašim), Rezekvítek (Brno), STREVLIK (Oldřichov v Hájích), Společnost prrátel prrírody (Liberec), SEVER (Horní Maršov), Sdružení TEREZA (Praha), Ekocentrum Skř́tek (Polička), Sluňákov - Centrum ekologických aktivit města Olomouc (Olomouc), Toulcův dvưr (Praha). 
Vzorek je tvořený šesti středisky působícími $v$ městech nad sto padesát tisíc obyvatel (Praha, Brno), pěti z měst velikosti sto až sto padesát tisíc obyvatel (Liberec, Olomouc, Pardubice), dvě z menších měst okresního významu (Vsetín, Vlašim) a šest z menších obcí (Velké Meziříčí, Krásensko, Oldřichov v Hájích, Horní Maršov, Polička).

Všem respondentům byla nabídnuta možnost anonymity, kterou však žádné středisko nevyužilo.

\section{Prezentace výsledků}

\section{Kategorie zdroje}

Při analýze evaluačních profilů středisek se vynořila klíčová kategorie, která rozdělila střediska do dvou hlavních skupin. Byla označena jako kategorii zdroje. Kategorie zdroje identifikuje výchozí pozici středisek při evaluaci programů. Tou je bud' autorita (lektor, pozorovatelé - lektoři, pozorovatelé - učitelé) nebo audience (žáci, děti, účastníci programu).

U středisek, které mají blíže k prvnímu pólu, je úsudek o kvalitě programu formulován na základě odborného názoru př́tomné autority. Ta program hodnotí pomocí nestandardizovaného nebo standardizovaného pozorování. Při nestandardizovaném pozorování se autorita zpravidla opírá o vlastní odborné zkušenosti, př́padně porovnává svá očekávání s realitou (reaktivní rovina evaluace). Při standardizovaném pozorování se využívají kriteriální tabulky, jako je Hodnotící tabulka SSEV Pavučina.

Střediska, která mají blíže ke druhému pólu kategorie zdroje, hodnotí kvalitu programu především podle výpovědí jeho účastníků (audience). Využívají přitom různé formy reflektivních a debriefingových technik s případným porovnáním názorů před programem a po něm, písemné reflexe dětí nebo aplikované metody pedagogického výzkumu - dotazníkové šetření či didaktické testy.

Zařazení středisek k jednomu či druhému pólu představuje jisté zjednodušení. Řada středisek experimentuje a přebírá do své práce prvky z různých inspiračních zdrojů, což platí i pro metodiku. Je proto oprávněnější mluvit spíše o jisté tendenci středisek preferovat první či druhý přístup. Předpokládáme také spíše kontinuální rozdělení středisek na ose autorita - audience, než jednoduché rozdělení do dvou skupin. Následující rozdělení je proto třeba chápat $v$ kontextu uvedených výhrad (umístění v rámci daného polokruhu nevyjadřuje míru blízkosti k příslušnému pólu).

\section{Obr. č. 2. Rozdělení středisek podle kategorie zdroje.}

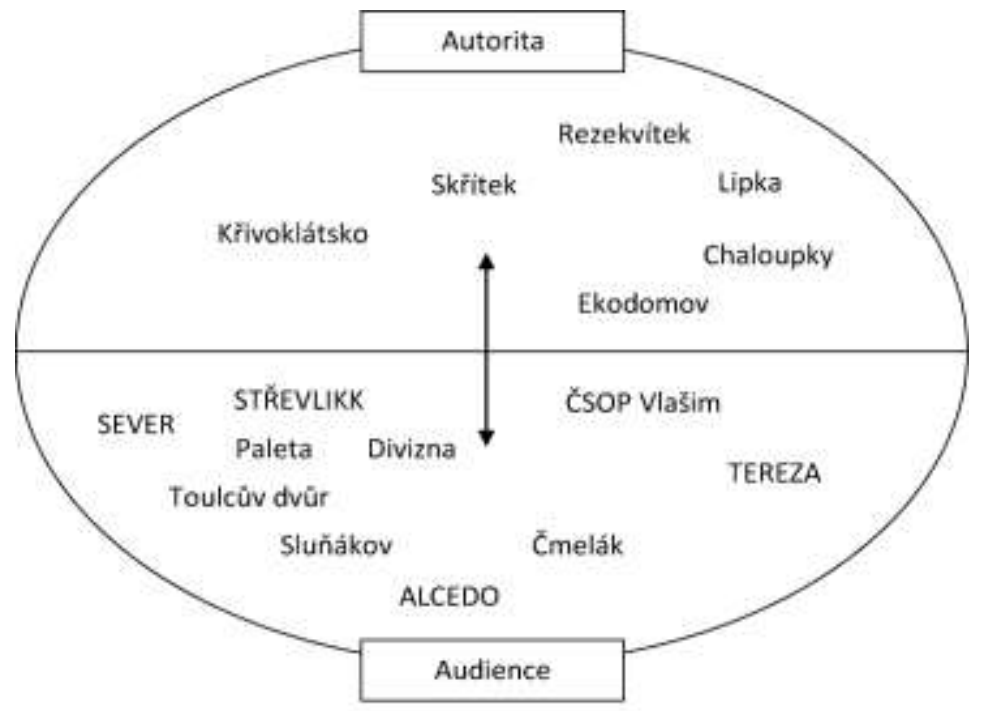


Pozn.: Horizontální čára odděluje od sebe střediska, která mají blíže k pólu autorita (v horní části kruhu) a střediska, jejichž evaluační strategie korespondují více s pólem audience (dolní část kruhu). Oboustranná šipka znázorňuje orientaci osy.

\section{Kategorie autonomie}

Po rozdělení středisek do dvou skupin podle kategorie zdroje byla z evaluačních profilů středisek vysledována vedlejší kategorie, která množinu opět rozděluje do dvou nestejně velkých skupin. Je jí kategorie autonomie, která nabývá pólư spolupráce a samostatnosti.

Ve střediscích, která volí strategie bližší pólu nezávislosti, hodnotí kvalitu programů nejčastěji samotný lektor, at' již pomocí nestandardizovaného vlastního pozorování nebo pomocí reflektivních metod, které do programu zařazuje.

Střediska, která preferují pól spolupráce, využívají jako hodnotitele jinou osobu, než je lektor. Tou může být jiný lektor, doprovázející učitel nebo externí evaluátor.

I v tomto př́padě si musíme být vědomi toho, že eklektický přístup středisek umožňuje existenci smíšených evaluačních strategií a kontinuálního rozmístění středisek po ose. Zařazení střediska do levého či pravého polokruhu je proto spíše odrazem jeho preferencí a směřování, než popisem převládající reality.

\section{Obr. č. 3. Rozdělení středisek podle kategorie autonomie.}

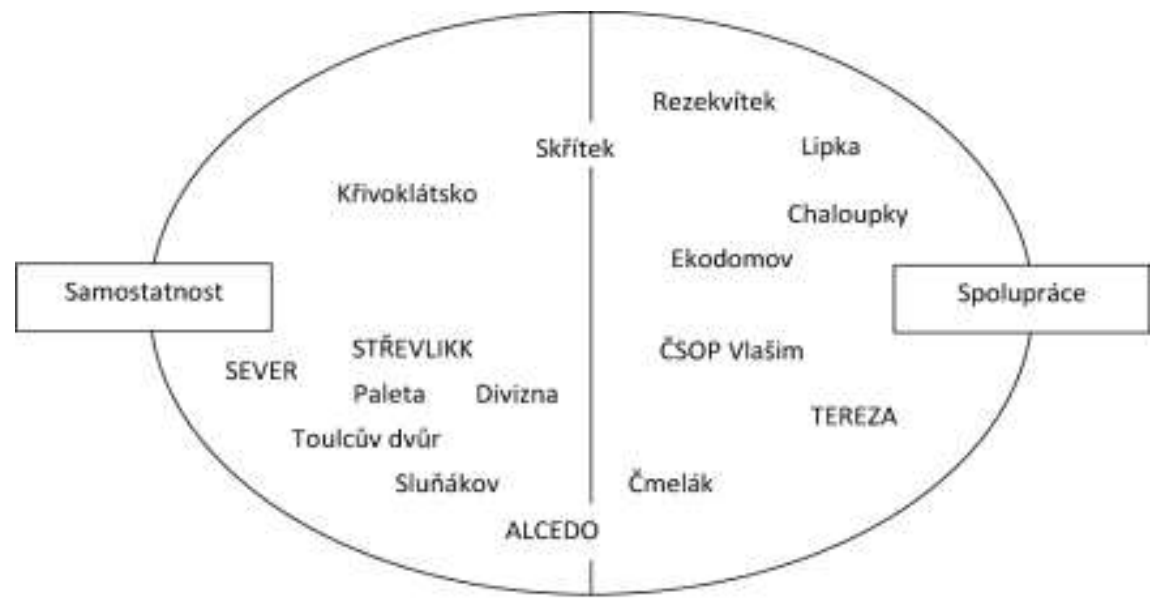

Pozn.: Vertikální čára odděluje od sebe střediska, která mají blíže k pólu samostatnost ( $v$ levé části kruhu) a střediska, jejichž evaluační strategie korespondují více s pólem spolupráce (pravá část kruhu). Oboustranná šipka znázorňuje orientaci osy.

\section{Kategorizace středisek podle os zdroje a autonomie}

Předcházející analýzy ukázaly, že pro kategorizaci evaluačních strategií používaných středisky jsou klíčové kategorie zdroje a kategorie autonomie. Obě kategorie vytvářejí osy, které rozdělují střediska vždy do dvou typů s předpokládanou kontinuitou přechodu mezi póly.

Složením obou os získáme čtyři kvadranty, z nichž každý vymezuje jednu z evaluačních strategií středisek. 
Obr. č. 4. Typy evaluačních strategií středisek podle kategorií zdroje a autonomie.

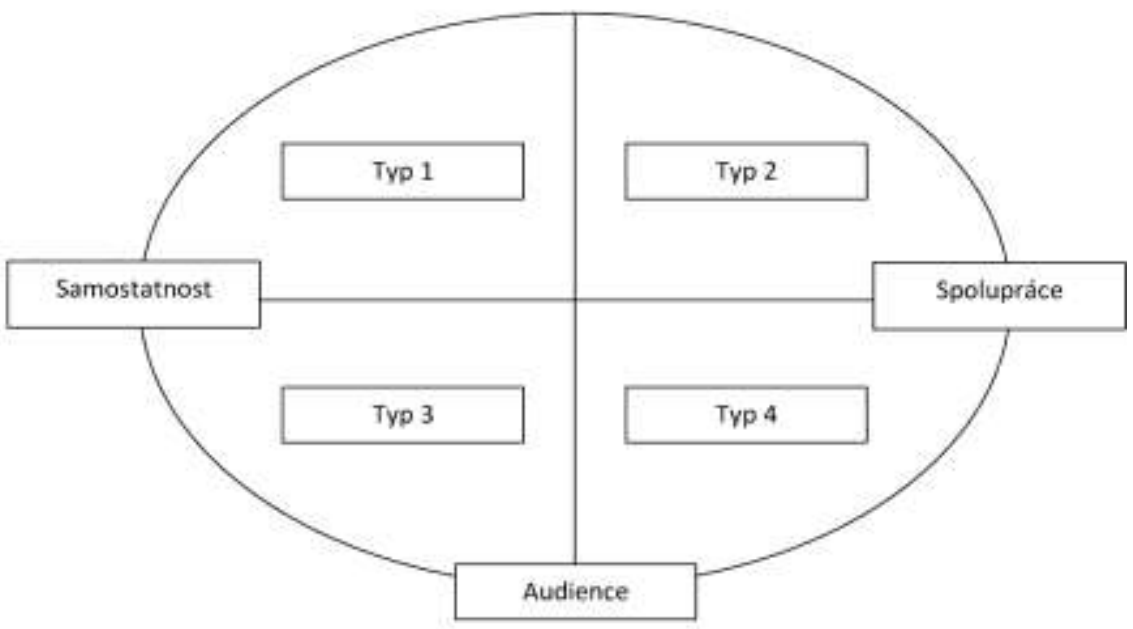

Ve střediscích Typu 1 hodnotí programy samotný lektor bez významné pomoci zvenčí. Lektor vychází z vlastních zkušeností, využívá pozorování či dlouhodobou vlastní práci se skupinou a nestrukturované zpětné vazby a reflexe epizodicky získané od žáků.

Střediska Typu 2 využívají pro hodnocení externí pozorovatele, jako jsou přihlížející učitelé, hospitující lektoři či pozorovatelé z jiných organizací. Typickým evaluačním nástrojem je nestrukturované pozorování nebo Hodnotící tabulka (viz príloha). Evaluace pak probíhá na poradě po ukončení programu na základě výsledků pozorování.

Střediska Typu 3 využívají pro hodnocení aktivní metody výuky vyplývající z různých modelů učení, jako je debriefing či evokace. Použitá metoda dává žákům přirozenou př́ležitost se projevit či reflektovat program, získané informace se pak stávají zdrojem hodnocení. Evaluace je součástí programu vedeného lektorem a lektor ji tak sám může vyhodnocovat.

Střediska Typu 4 se snaží výstupy od žáků analyzovat pomocí komplexně zpracovaných evaluací, využívajících kombinaci výzkumných metod, jako jsou dotazníky, didaktické testy, ale i strukturované pozorování, analýza žákovských písemných výstupů a další. Evaluace zpravidla vychází z porovnávání výsledků experimentální a kontrolní skupiny či stavu sledovaných proměnných před programem a po něm. Evaluační strategie Typu 4 je ve srovnání s ostatními strategiemi nejnáročnější, současně ale nejlépe splňuje zásady pro evaluaci programů a $v$ největší míře aplikuje metodologické zásady kvalitativního či kvantitativního pedagogického výzkumu. Protože střediska tohoto typu nemají vnitřní zdroje pro samostatné zpracování takto pojatých evaluací, spojují se s externím partnerem, nebo takového partnera hledají.

Nyní se pokusíme na základě získaných informací jednotlivá střediska rozmístit do příslušných kvadrantů: 
Obr. č. 5. Rozdělení SEV podle preferovaných evaluačních strategií.

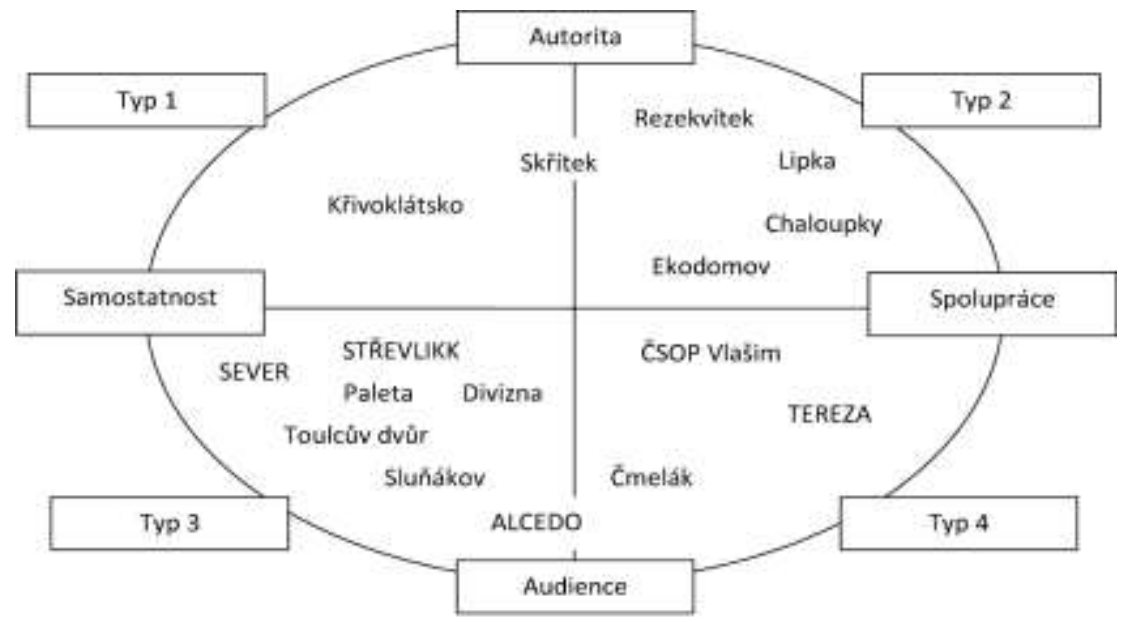

Zařazení středisek do kvadrantů není absolutní a vyjadřuje spíše preferovaný názor střediska na evaluaci. Např. ČSOP Vlašim a Čmelák byly do Typu 4 zařazeny díky evaluaci jediného programu, který ovšem považují za perspektivní pro svoje další směřování. Obdobně Sdružení TEREZA mělo v době zpracování výzkumu komplexně evaluovaný pouze jeden z nabízených programů (Ekoškola), na rok 2009 ale plánuje postupně vyhodnocovat další. ALCEDO o evaluaci Typu 4 zatím jen usiluje. Středisko SEVER projevilo zájem o externí evaluaci jednoho ze svých programů krátce po ukončení tohoto výzkumu a zůstalo proto zařazeno do Typu 3.

Přestože použití Hodnotící tabulky nejvíce koresponduje s evaluační strategií Typu 2, vzhledem k eklektickému př́stupu středisek a jejich spolupráci v rámci SSEV Pavučina se používá i u Typu 3 a Typu 4. Nemá zde ale dominantní roli a stává se spíše doplňujícím nástrojem.

Můžeme předpokládat, že obě základní kategorie souvisí s dalšími proměnnými. $\checkmark$ další části výzkumu se je pokusíme dále zmapovat.

\section{Související proměnné}

První zkoumaný předpoklad byl, že zařazení střediska na ose zdroje souvisí s preferovanou metodikou práce. Lze očekávat, že střediska bližící se k pólu autorita uplatňují spíše logocentrické a střediska směřující k pólu audience spíše pedocentrické metodické prístupy. ${ }^{1}$

Pedocentrismus vs. logocentrismus jsou ale velmi široké kategorie a jejich jednoznačné přiřazení $k$ jednomu či druhému pólu kategorie autority by pravděpodobně vedlo k př́lišnému zjednodušení reality. Střediska navíc uplatňují širokou škálu metod; v nabídce jednoho střediska je tak možné najít jak programy spíše logocentrické, tak programy orientované pedocentricky. $\vee$ rámci výzkumu proto tuto otázku ponecháváme

\footnotetext{
${ }^{1} \mathrm{~V}$ rámci výzkumu je logocentrismus i pedocentrismus chápán jako relevantní východisko pro volbu metodiky environmentální výchovy.
} 
otevřenou a budeme ji zkoumat pouze v omezené míře pomocí souvisejících proměnných. Těmi jsou kategorie prezentace a kategorie teambuildingu.

\section{Kategorie prezentace}

Způsob, jakým střediska propagují své programy v nabídce pro veřejnost, je ovlivněný více faktory, například marketingovými. Současně image, jakou si organizace vytváří, pramení i z reflektované identity organizace a jejího preferovaného směřování. Je možné předpokládat, že určitým odrazem této reflexe je i to, jak střediska o svých programech informují klienty - školy.

Sledovaná kategorie prezentace může nabývat dvou základních hodnot: orientace na výstupy a orientace na obsah. Střediska, která se v prezentaci programů orientují na výstupy, informují učitele o tom, jaké znalosti, tj. vědomosti, dovednosti či postoje žáci v programu získají. Střediska orientovaná na obsah referují o tom, z jakých témat se program skládá, co budou žáci $v$ jeho průběhu dělat a jaké informace jim budou předávány.

Předpokládali jsme, že s autoritativním pólem bude souviset orientace na obsah a s audienčním orientace na výstupy. ${ }^{2}$ Tento předpoklad se potvrdil. Přestože orientace na výstupy se objevila v prezentacích jen části středisek ze spodního polokruhu (viz obr. č. 6), všechna střediska orientovaná na autoritu prezentují své programy z hlediska obsahu:

Obr. č. 6. Prezentace programů středisky.

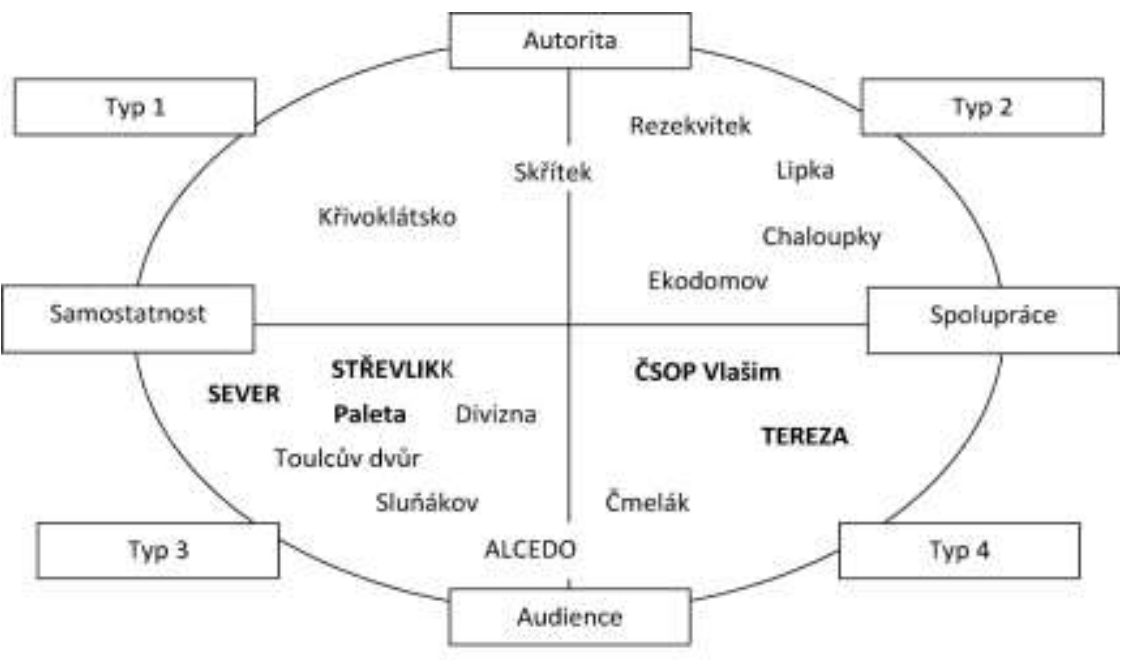

\footnotetext{
2 Předpoklad je trochu problematický z toho důvodu, že přesné formulace očekávaných výstupů jsou typickým rysem spíše logocentrických přístupů, zatímco přístupy pedocentrické dávají důraz na otevírání možnosti žáků nastavit si vlastní cíle, individualizovat výuku a dávat prostor pro otázky, které se vynoří v průběhu lekcí. Takto postavené programy jsou ale pro česká střediska velmi netypické, obvyklejší je přístup, kdy jsou programy předem vytvořeny a žáci mají prostor pouze pro jejich dílčí modifikace a pro samostatnou interpretaci probíraného. Můžeme proto předpokládat, že vymezení výstupů z hlediska žáka může indikovat větší zájem tvůrců programu o zohlednění žákovského hlediska, zatímco vymezení z hlediska tématu či učitelem ř́zených procesů větší důraz kladený na přenášené znalosti, dovednosti či postoje.
} 
Pozn.: Tučně jsou vyznačena střediska, která prezentují své programy z hlediska výstupů. Obyčejným písmem jsou zachycena střediska, která své programy prezentují z hlediska obsahu.

\section{Kategorie teambuildingu}

Dalším předpokladem bylo, že strediska orientovaná na audienci budou pravděpodobně do programu zařazovat prvky pro formování skupiny a to bud' jako součást pobytových akcí nebo jako samostatné výukové programy. Naopak strediska orientovaná na autoritu by tyto prvky využívat neměla. ${ }^{3}$

Pro vyhodnocení byly analyzovány nabídky programů jednotlivých středisek, u některých jsme předpoklady ověřovali dotazy v rozhovorech.

I tento předpoklad se potvrdil. Střediska, v jejichž programech je inzerována práce se skupinou či která nabízí programy na osobnostní a sociální rozvoj účastníků (teambuilding, rozvoj kooperativních a komunikačních dovedností, atd.) jsou v následujícím schématu znázorněna tučně:

Obr. č. 7. Teambuilding v programech středisek.

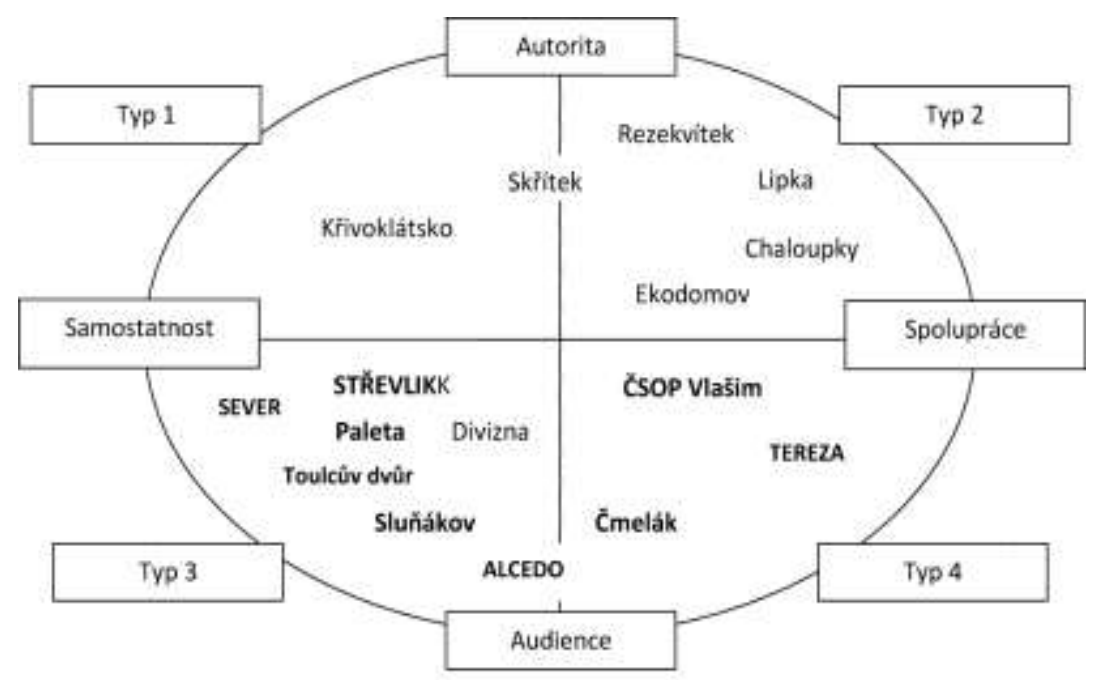

Pozn.: Tučně jsou vyznačena střediska, která mají v nabídce programů teambuildingové prvky. Obyčejným písmem jsou zachycena střediska, která teambuilding ve svých programech neuvádí.

S výjimkou střediska Divizna pracují se skupinou všechna střediska orientovaná na audienci, naopak žádné ze středisek orientovaných na autoritu.

3 Předpokládáme zde, že střediska více orientovaná na žáky budou mít větší zájem ovlivňovat ve svých programech vztahy ve skupině a související sociální dovednosti žáků, protože budou používat metodiky umožňující určitou míru přizpůsobování programu skupině a skupinou, zatímco střediska více orientovaná na přenášenou látku budou používat metodiky, ve kterých nehraje sociální klima ve skupině takovou roli. 
Zaměření prezentace na výstupy vs. obsah a zařazení/nezařazení práce se skupinou do programu pouze indikují, ale jednoznačně neurčují orientaci střediska ke spíše logocentrické, resp. paidocentrické metodice. V rámci výzkumu současně nechceme uplatněné metodiky hodnotit. Je legitimní, že střediska čerpají z různých pedagogických východisek, stejně jako fakt, že volí rưzné evaluační strategie. Souvislost mezi metodickými východisky programů a volbou evaluační strategie můžeme považovat za pravděpodobnou, ale nikoliv prokázanou.

\section{Kategorie sebehodnocení}

Nyní se zaměříme na analýzu proměnných souvisejících s osou autonomie. Prvním předpokladem bylo, že rozhodnutí o tom, zda hodnotitelem programu bude samotný lektor nebo jiná osoba, bude souviset se sebehodnocením organizace. Kategorii sebehodnocení můžeme opět znázornit jako osu definovanou pólem spokojenosti a kritičnosti střediska k vlastní práci. Střediska kritičtější ke své práci by podle posuzovaného předpokladu měla inklinovat spíše k Typům 2 a 4, charakterizovaným spoluprácí s externími hodnotiteli a využitím komplexnějších evaluačních strategií.

Hodnocení této kategorie bylo obtížnější, protože všechna dotazovaná střediska projevila jistý stupeň kritičnosti ke své práci. Ze středisek v pravé polovině obrázku č. 5 byl vyšší stupeň kritičnosti patrný u středisek Čmelák a ČsoP Vlašim. Obě střediska v současnosti usilují o nové pojetí svých programů. "Zdálo se nám, že ty dvouhodinové programy nemají dopad. (...) Je to taková služba školám, ale o to nám nejde. Lákalo nás mít skupinu, kterou znám, vím co od ní můžu očekávat, můžu s ní pracovat dlouhodobě. Chtěli jsme to vyhodnotit..." (ČSOP Vlašim) V podobné situaci je středisko Rezekvítek, které $v$ tomto školním roce zahájilo po předchozích spíše ochranářsky laděných projektech nabídku EVP. Určitou míru sebekritičnosti vyjádřilo i Sdružení TEREZA, když se otevřelo evaluaci svých zaběhnutých programů.

Naopak střediska SEVER, Divizna a Sluňákov jsou se svojí metodikou spíše spokojena a problémy vidí $v$ drobnostech nebo ve vnějších faktorech. Těmi jsou například problémy související s fluktuací lektorů a nutností zaučování nových lektorů do stávajících programů (Divizna, SEVER), ekonomické faktory, které středisko nutí dělat výdělečnější krátké programy, přestože to není jeho priorita (SEVER), nedotaženost detailů (Sluňákov), přetíženost lektorů (Sluňákov, SEVER). Střediska současně necítí potřebu stávající metodiku nějak zásadně měnit: "základ (naší metodiky) je dobrý - je to naše rodinné stříbro... připadá nám, že ten program je natolik dobře poskládaný, že si nemyslím, že to je špatně. Kdyby to měl být celé nesmysl, tak opravdu nevím, jak to udělat jinak..." (SEVER)

Pozitivní sebehodnocení dále můžeme vyčíst z písemných vypovědí sdružení Křivoklátsko.

Zjištěné nálezy naznačují, že mezi zařazením střediska na osu autonomie a jeho sebehodnocením mohou existovat souvislosti. Střediska usilující o systémovou změnu metodiky preferují (nebo o ní uvažují) evaluaci s využitím externích zdrojů, zatímco střediska v daném období spokojená se svojí metodikou patrně častěji vystačí s hodnocením vlastními prostředky.

\section{Kategorie Hodnotící tabulka (viz příloha)}

K míre využívanosti Hodnotící tabulky se střediska vyjadřovala v první, dotazníkové části výzkumu. Z výsledků vyplynul předpoklad, že Hodnotící tabulka jako evaluační nástroj bude nejlépe vyhovovat střediskům druhého typu, zatímco u středisek jiných typů se proti tomuto evaluačnímu nástroji budou objevovat výhrady. Předpoklad byl dále ověřován pomocí rozhovorů se zástupci středisek ČSOP Vlašim a Sluňákov. Obě střediska připustila užitečnost Hodnotící tabulky, ale současně k ní připojila kritické výhrady. Význam Hodnotící tabulky byl oběma středisky spatřován především $v$ metodické pomoci pro začínající střediska nebo lektory, dále jako určité vodítko, podle kterého vést rozbor 
provedení programu s lektory. Dobře hodnocené je také to, že Hodnotící tabulka definuje základní oblasti, kterých by si lektor měl všímat.

Na druhé straně je Hodnotící tabulka hodnocena jako přiliš složitá, svazující, systém bodování může "deptat lektora" (Sluňákov). Některé hodnocené oblasti jsou považovány za irelevantní "já v programu o globálních problémech pro střední školu nemám potřebu vyrobit si výrobek" (ČSOP Vlašim). Zásadní omezení pak ČSOP Vlašim vidí v tom, že "tabulka hodnotí program a nikoliv dopady. A to je trochu málo. Nejde o to dělat programy podle tabulky, ale tak, aby měly nějaký dopad."

Hodnotící tabulku také nikdy nepoužívá STŘEVLIK. Na druhé straně řada středisek zařazených do třetího či čtvrtého kvadrantu (Alcedo, Čmelák, SEVER, Paleta a další) Hodnotící tabulku používá nebo se ji chystá používat. Předpokládaná souvislost mezi zařazením střediska do některého z kvadrantů a kritickým názorem na Hodnotící tabulku proto není zcela potvrzená. Řada středisek navíc v současné době Hodnotící tabulku teprve objevuje a nemá na ni zformulovaný názor. Na základě nestandardizovaného pozorování autora tohoto výzkumu na Veletrhu EVP v září 2008 se Hodnotící tabulka mezi lektory středisek jeví jako nový, zajímavý, ale i kontroverzní nástroj.

\section{Kategorie preferencí}

Z analýzy výpovědí středisek se jako nová proměnná objevila kategorie preferencí. Kategorie má charakter vektoru vyjadřujícího zájem střediska přesunout se z jednoho kvadrantu do jiného.

Ve všech případech směřovaly preference středisek od pólu samostatnosti k pólu spolupráce. To se týká zejména přesunu středisek z Typu 3 do Typu 4, kterým prošli, procházejí či chtějí projít Alcedo, Sdružení TEREZA, Čmelák i ČSOP Vlašim. Zájem o posun vyjádřilo také středisko SEVER: "co chybí, je hodnocení cillo a to potřebujeme".

Ve vztahu k horní částí obrázku č. 5 můžeme sledovat obdobný přesun středisek z Typu 1 do Typu 2, současně střediska, která využívala hodnocení od externích pozorovatelů posilují svoji evaluační strategii využíváním Hodnotící tabulky.

Směr vyjádřených preferencí naznačuje, že pokud střediska nejsou spokojena se svojí stávající evaluační strategií, volí postupy využívající spolupráce s externími pozorovateli nebo hodnotiteli. Opačně orientované preference nebyly ve výpovědích respondentů zaznamenány.

\section{Evaluační strategie: vztahy mezi proměnnými}

S jistým zjednodušením nyní můžeme podrobněji popsat střediska podle jednotlivých typů preferovaných evaluačních strategií. 
Obr. č. 8. Vztahy mezi proměnnými.

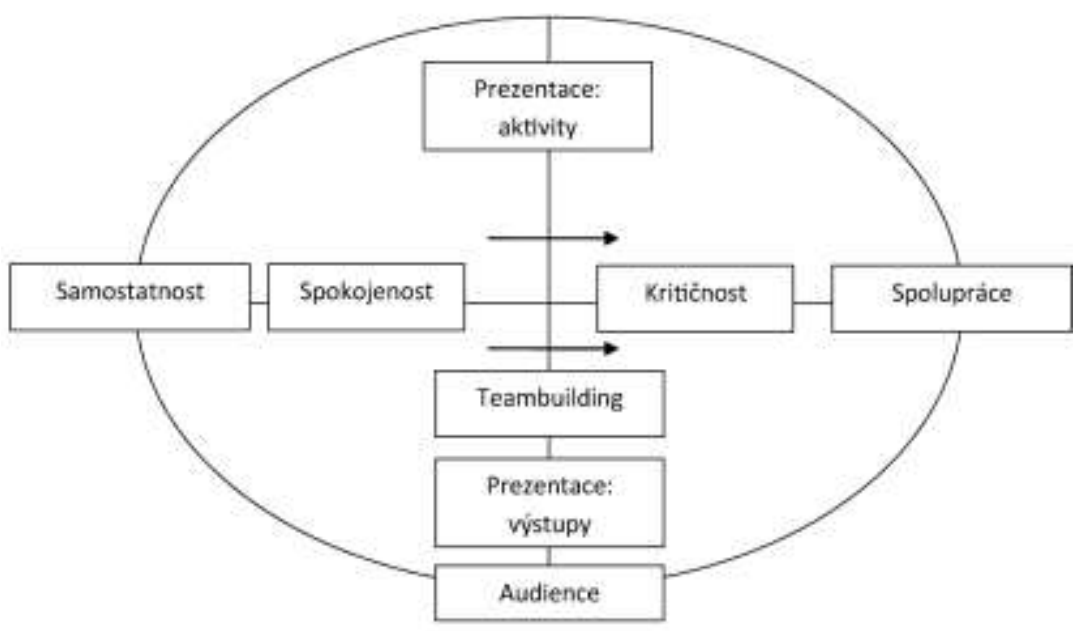

Střediska Typu 1 preferují hodnocení vycházející z odborné zkušenosti samotného lektora metodou nestandardizovaného pozorování. Střediska jsou bud' se svoji metodikou spokojená, nebo uvažují o použití Hodnotící tabulky a přesun do druhého kvadrantu. Svoje programy prezentují popisem probíhajících aktivit. $\mathrm{V}$ programech nepracují s rozvíjením skupinové dynamiky. Preferovaná metodika pravděpodobně vykazuje logocentrickou orientaci, tj. hlavní pozornost je věnována předávání zvolené sumy poznatků s centrální rolí lektora jako zdroje předávaných informací. Předpokládáme, že myšlenkově se střediska hlásí k faktografické tradici environmentální výchovy čerpající z esencialistické filozofie výchovy. (Östman \& Öhman, 2007)

Střediska Typu 2 se od prvního typu odlišují zejména vyšší mírou kritické reflexe své práce. To je vede $\mathrm{k}$ využití externích pozorovatelů $v$ roli hodnotitelů programu a k využívání nástrojů pro standardizované pozorování, jako je Hodnotící tabulka. Střediska tohoto typu považují Hodnotící tabulku za optimální evaluační nástroj pro svoji metodiku.

Ve strediscích Typu 3 je hlavním hodnotitelem lektor programu, který vychází $z$ analýz reflexí žáků $v$ průběhu programu. Střediska tohoto typu zpravidla prezentují své programy $z$ pohledu žáků a aktivně rozvíjejí vztahy ve skupině. $K$ tomu uplatňují prvky zážitkové pedagogiky, konstruktivismu, globální výchovy. Myšlenkově se pravděpodobně blízí k normativní tradici environmentální výchovy vycházející z progresivistické filozofie. (Östman \& Öhman, 2007) Střediska si uvědomují drobné nedostatky realizovaných programů, ty ale vidí spiśs $v$ personálních či finančních problémech, než $v$ používané metodice, se kterou jsou spíše spokojeni. $V$ prípadě nespokojenosti střediska hledají spolupráci s externím evaluátorem a směřují k Typu 4.

Některá ze středisek zařazených do třetího kvadrantu se z důvodu potřeby kriticky analyzovat své programy přesunula do Typu 4. Tento typ sdílí stejná pedagogická východiska s předchozím typem. Pro evaluaci programů začala tato střediska používat sofistikovanější evaluační nástroje založené na komplexní analýze výstupů metodami pedagogického výzkumu. $Z$ důvodu náročnosti těchto postupů střediska hledají spolupráci s externími partnery, jako jsou univerzity nebo pedagogicko-psychologické poradny.

\section{Diskuse a závěry}

Diskuse o evaluaci programů je mezi středisky ekologické výchovy poměrně nová, $\checkmark$ posledních dvou letech je jí ale věnována značná pozornost díky práci Pracovní skupiny SSEV Pavučina pro kvalitu EVP a díky vývoji a propagaci jejího hlavního výstupu 
- Hodnotící tabulky, definující standardy kvalitního programu. Přestože obecný názor mezi středisky je takový, že evaluace je důležitá, v jejím uplatnění se střediska značně odlišují.

$\checkmark$ př́stupu středisek $k$ evaluaci můžeme rozlišit čtyři hlavní strategie, které se odlišují v názoru na klíčový zdroj dat pro evaluaci (autorita vs. audience, tj. zda je zdrojem pro hodnocení odborný názor prítomného experta nebo názory dětí) a autonomii evaluace (samostatné hodnocení lektorem vs. spolupráce s externím hodnotitelem). Volba evaluační strategie dále souvisí s dalšími proměnnými, jako jsou metodika preferovaná střediskem a spokojenost střediska se svou prací. Vzhledem $\mathrm{k}$ tomu, že se podařilo získat data jen od necelé poloviny středisek SSEV Pavučina, nemůžeme míru jejich zastoupení do jednotlivých typů kvantifikovat. $V$ rámci posuzovaného vzorku převažovala střediska Typu 3, tj. střediska, která preferují pedocentrické metodiky a využívají aktivní formy učení pro získání zpětné vazby od žáků.

Nejpoužívanější metody jsou zatím založeny na nestandardizovaném či standardizovaném pozorování. Při nestandardizovaném pozorování středisko bud' vychází ze zkušeností a intuice lektora, nebo využivá aktivních výukových metod pro získání výpovědí od žáků (reflexe, debriefing). Pro standardizované hodnocení se používá zejména Hodnotící tabulka.

Názory na Hodnotící tabulku se rozcházejí od jejího vyzdvihování až po odmítání. Postoj středisek k Hodnotící tabulce souvisí s jejich preferovanou evaluační strategií - střediska, která jsou k Hodnotící tabulce kritická, upřednostňují evaluační strategie založené na výpovědích od dětí a na hodnocení výstupů programu. Největší uplatnění dojde Hodnotící tabulka pravděpodobně u středisek Typu 2, tj. těch, které používají spíše logocentricky orientovanou metodiku a současně jsou kritičtější ke své práci.

Většina středisek nepoužívá pro evaluaci žádné statistické metody zpracování získaných dat kromě deskriptivní statistiky (průměry). Výjimkou jsou střediska Typu 4, která se rozhodla pro komplexní evaluaci s využitím metod aplikovaného pedagogického výzkumu (tj. metod založených např. na porovnávání experimentální a kontrolní skupiny či stavu sledovaných proměnných před programem a po něm). Tato strategie je ale závislá na spolupráci s externím partnerem, nebot' střediska zatím nejsou schopna výzkumy vlastními prostředky realizovat.

S výjimkou středisek Typu 4 převažuje u středisek formativní evaluace nad sumativní. Jako určitý paradox můžeme vidět fakt, že střediska Typu 1 a 2 , která jsou spíše logocentricky orientovaná, preferují pro evaluaci metodu pozorování, která je typicky kvalitativním nástrojem uplatňovaným $v$ zahraničí spíše pro evaluaci pedocentricky orientovaných programů. Střediska ze čtvrtého kvadrantu, která jsou orientována na potřeby žáků a skupiny zase směřují k evaluacím vhodným pro výstupově orientované programy. (srv. Hart \& Nolan, 1999; Sterling, 2001; Stokking, van Aert, Meijberg, \& Kaskens, 1999) Tento paradox považujeme za vývojové stádium související s krátkou dobou trvání diskuse o evaluaci středisek. Lze předpokládat, že se střediska Typu 2 časem transformují směrem k výstupově orientované environmentální výchově, zatímco střediska typu 3 a 4 začnou ve větší míre využívat smíšený design evaluací. 
Př́loha: Hodnotící tabulka

\begin{tabular}{|c|c|c|c|c|c|c|}
\hline & \multicolumn{6}{|c|}{$\begin{array}{l}\text { HODNOTICÍ TABULKA PRO EVP } \\
\text { (vytvořená pro vnitřní potřebu SSEV Pavučina, nedílnou součástí je manuál } \\
\text { k použití hodnoticí tabulky) }\end{array}$} \\
\hline \multicolumn{2}{|l|}{ Datum: } & \multicolumn{5}{|c|}{ Hodnotící (pracovní) pozice: } \\
\hline \multicolumn{2}{|c|}{ Název programu: } & \multicolumn{5}{|c|}{ Škola, ročník: } \\
\hline \multicolumn{2}{|l|}{ Pracoviště: } & \multicolumn{5}{|c|}{ Počet žáků: } \\
\hline \multicolumn{2}{|l|}{ Lektor: } & \multicolumn{3}{|c|}{ 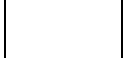 } & \\
\hline Ukazatele & Dílčí jevy & & $\mathrm{dn}$ & 100 & sení & Doplňující připomínky \\
\hline \multirow{3}{*}{$\begin{array}{l}\text { Plánování a } \\
\text { příprava } \\
\text { EVP }\end{array}$} & $\begin{array}{l}1 \text { Formulace cílů EVP (vhodná } \\
\text { formulace, environmentální rozměr) }\end{array}$ & 4 & 3 & 2 & 1 & \\
\hline & $\begin{array}{l}2 \text { Promyšlený systém hodnocení } \\
\text { dosažení svých cílů }\end{array}$ & 4 & 3 & 2 & 1 & \\
\hline & 3 Písemná podoba EVP & 4 & 3 & 2 & 1 & \\
\hline \multirow{4}{*}{ Obsah EVP } & 4 Odborná správnost a aktuálnost & 4 & 3 & 2 & 1 & \\
\hline & $\begin{array}{l}5 \text { Obsah adekvátní věku účastníků, } \\
\text { cílům, tématu a délce EVP }\end{array}$ & 4 & 3 & 2 & 1 & \\
\hline & $\begin{array}{l}6 \text { Důraz na souvislosti a řešení } \\
\text { problémů ŽP }\end{array}$ & 4 & 3 & 2 & 1 & \\
\hline & 7 Návaznost na vzdělávací standardy & 4 & 3 & 2 & 1 & \\
\hline \multirow{5}{*}{$\begin{array}{l}\text { Metody a } \\
\text { formy EVP }\end{array}$} & $\begin{array}{l}8 \text { Metody adekvátní věku účastníků, } \\
\text { cílům, tématu a délce EVP }\end{array}$ & 4 & 3 & 2 & 1 & \\
\hline & $\begin{array}{l}9 \text { Využívání aktivizujících } \\
\text { a interaktivních metod }\end{array}$ & 4 & 3 & 2 & 1 & \\
\hline & 10 Skupinová práce & 4 & 3 & 2 & 1 & \\
\hline & $\begin{array}{l}11 \text { Přímý kontakt s přírodou, } \\
\text { přírodninami }\end{array}$ & 4 & 3 & 2 & 1 & \\
\hline & 12 Praktické činnosti & 4 & 3 & 2 & 1 & \\
\hline \multirow{2}{*}{$\begin{array}{l}\text { Příhodné } \\
\text { podmínky }\end{array}$} & 13 Kvalitní učební pomůcky & 4 & 3 & 2 & 1 & \\
\hline & 14 Příznivé prostředí & 4 & 3 & 2 & 1 & \\
\hline \multirow{3}{*}{$\begin{array}{l}\text { Účinnost } \\
\text { motivace }\end{array}$} & $\begin{array}{l}15 \text { Soulad mezi sdělovanými postoji } \\
\text { a chováním lektora } v \text { průběhu programu }\end{array}$ & 4 & 3 & 2 & 1 & \\
\hline & 16 Propojení teorie a praxe & 4 & 3 & 2 & 1 & \\
\hline & $\begin{array}{l}17 \text { Využití znalostí, dovedností } \\
\text { a zkušeností účastníků }\end{array}$ & 4 & 3 & 2 & 1 & \\
\hline \multirow{3}{*}{$\begin{array}{l}\text { Interakce a } \\
\text { komunikace }\end{array}$} & $\begin{array}{l}18 \text { Představení střediska, lektorů } \\
\text { a programu }\end{array}$ & 4 & 3 & 2 & 1 & \\
\hline & $\begin{array}{l}19 \text { Ujasnění pravidel chování } \\
\text { a komunikace mezi lektory a účastníky }\end{array}$ & 4 & 3 & 2 & 1 & \\
\hline & $\begin{array}{l}20 \text { Navození a podpora vzájemné } \\
\text { komunikace (včetně rozvoje schopnosti }\end{array}$ & 4 & 32 & 2 & 1 & \\
\hline
\end{tabular}




\begin{tabular}{|c|c|c|c|c|c|c|}
\hline & \multicolumn{4}{|l|}{ naslouchat druhému) } & & \\
\hline & 21 Podpora spolupráce & 4 & 3 & 2 & & \\
\hline & $\begin{array}{l}22 \text { Prostor a podpora vyjádřit názor, } \\
\text { nápad }\end{array}$ & 4 & 3 & 2 & 1 & \\
\hline & $\begin{array}{l}23 \text { Ujasnění role učitele při EVP včetně } \\
\text { žádosti o zpětnou vazbu }\end{array}$ & 4 & 3 & 2 & 1 & \\
\hline & $\begin{array}{l}24 \text { Vnímavost situace a bezpečná } \\
\text { atmosféra }\end{array}$ & $4: 7$ & 3 & 2 & 1 & \\
\hline \multirow{2}{*}{$\begin{array}{l}\text { Zpětná } \\
\text { vazba }\end{array}$} & $\begin{array}{l}25 \text { Kladná zpětná vazba na aktivity } \\
\text { účastníků související s programem }\end{array}$ & $4: 5$ & 3 & 2 & 1 & \\
\hline & $\begin{array}{l}26 \text { Závěrečná reflexe / opakování (dle } \\
\text { použité metodiky) s aktivní účastí } \\
\text { přítomných }\end{array}$ & 4 & 3 & 2 & 1 & \\
\hline \multirow{2}{*}{$\begin{array}{l}\text { Vystupování } \\
\text { lektora }\end{array}$} & $\begin{array}{l}27 \text { Pohyb a výrazové prostředky } \\
\text { lektora }\end{array}$ & $4: 7$ & 3 & 2 & 1 & \\
\hline & $\begin{array}{l}28 \text { Kultivovaný projev lektora (mluva, } \\
\text { hlas, písemný projev) }\end{array}$ & 4 & 3 & 2 & 1 & \\
\hline \multirow{2}{*}{$\begin{array}{l}\text { Struktura } \\
\text { EVP a jiné }\end{array}$} & $\begin{array}{l}29 \text { Realizovaná struktura EVP (např. } \\
\text { cíl, motivace, činnosti, závěr) }\end{array}$ & 4 & 3 & 2 & 1 & \\
\hline & 30 Dosažení cílů & 4 & 3 & 2 & 1 & \\
\hline \multirow{2}{*}{$\begin{array}{l}\text { Doplňující } \\
\text { komentáře }\end{array}$} & 31 Doplňující komentář k programu & \multicolumn{4}{|c|}{$\begin{array}{l}\text { volná } \\
\text { odpověd' }\end{array}$} & \\
\hline & 32 Doplňující komentář k lektorovi & \multicolumn{4}{|c|}{$\begin{array}{l}\text { volná } \\
\text { odpověd' }\end{array}$} & \\
\hline
\end{tabular}

\section{Literatura}

- ALCEDO . . Retrieved from http://www.alcedo-vs.cz/nabidka-pro-skoly/jednodennivylety.html

- Český svaz ochránců prírody Vlašim . . Retrieved from http://www.csopvlasim.cz/eko vych.php

- Duvall, J., Higgs, A., \& VOLSKE, Kim. Evaluation, (2007). What it is and why do it?. . Retrieved from http://meera.snre.umich.edu/plan-an-evaluation/evaluation-what-is-it-andwhy-do-it

- DIVIZNA .. Retrieved from http://www.zooliberec.cz/divizna/

- EKOCENTRUM Paleta . . Retrieved from http://www.paleta.cz/

- EKOCENTRUM Skřítek . . Retrieved from http://www.ekocentrumskritek.cz/

- EKODOMOV .. Retrieved from http://www.ekodomov.cz/index.php?id=vyukove programy

- Hart, P., \& Nolan, K. (1999). A critical analysis of research in environmental education. Studies in Science Education, 34(1), 1-69. Retrieved from http://www.tandfonline.com/doi/abs/10.1080/03057269908560148 http://dx.doi.org/10.1080/03057269908560148

- $\quad$ I.S. Krrivoklátsko . . Retrieved from http://www.is-krivoklat.cz 
- Jančaříková, K. (2007). Žákovské portfolio - vhodná forma hodnocení environmentální výchovy. Envigogika, 3, 1802-3061. Retrieved from http://www.envigogika.cuni.cz/index.php/Envigogika/article/view/23

- Kvasničková, D. .Výroční zpráva Klubu ekologické výchovy. . Retrieved from http://www.generalhonza.wz.cz/vz2007.pdf

- Máchal, A., Činčera, J., Daňková, L., \& Broukal, V. (2008). Ekopedagogova osmero 2007. Praha: Pavučina.

- Ostrůvek - programy pro 1. stupeň ZŠ . . Retrieved from http://www.chaloupky.cz/ostruvek--programy-pro-1.-stupen-zs.html

- Östman, L., \& Öhman, J. (2007). Selective traditions within Environmental Education. Durban: World Environmental Education Congress.

- Pavučina, (2008). Činnost SSEV Pavučina. . Retrieved from http://www.pavucinasev.cz/pavucina.htm

- Sdružení TEREZA Ekoškola. Kritéria pro získání titulu Ekoškola. . . Retrieved from http://ekoskola.cz/images/stories/materialy/kriteria.pdf

- Sdružení TEREZA . . Retrieved from http://www.terezanet.cz/programy/2az5trida/

- SEVER - Středisko ekologické výchovy a etiky Rýchory . . Retrieved from http://www.sever.ekologickavychova.cz

- SPP - Společnost přátel př́rody . . Retrieved from http://www.cmelak.cz/vychova/programy ss.html

- Sterling, S. (2001). Sustainable education. Re-visioning Learning and Change. Bristol: The Schumacher Society.

- Stokking, H., van Aert, L., Meijberg, W., \& Kaskens, A. (1999). Evaluating Evironmental Education. : IUCN Commission on Education and Communication CEC. Retrieved from http://www.iucn.org/wp2003/books/pdf/cec4.pdf

- Střevlik (2008). . Retrieved from http://www.strevlik.cz

- Švař́čček, R., \& Šed'ová, K. (2007). Kvalitativní výzkum v pedagogických vědách. Praha: Portál.

- Toulcův dvůr . . Retrieved from http://www.toulcuvdvur.cz/ss.asp

- Vlašim, Z. . (2007). ZO ČSOP Vlašim. Expedice 4P. Vlašim: Podblanické ekocentrum ČSOP Vlašim. 
Časopis Envigogika vydává Centrum pro otázky životního prostředí UK. Vývoj časopisu je podpořen projektem OP VK Mezioborová sít udržitelného rozvoje.

Více najdete na internetových stránkách projektu mosur.czp.cuni.cz
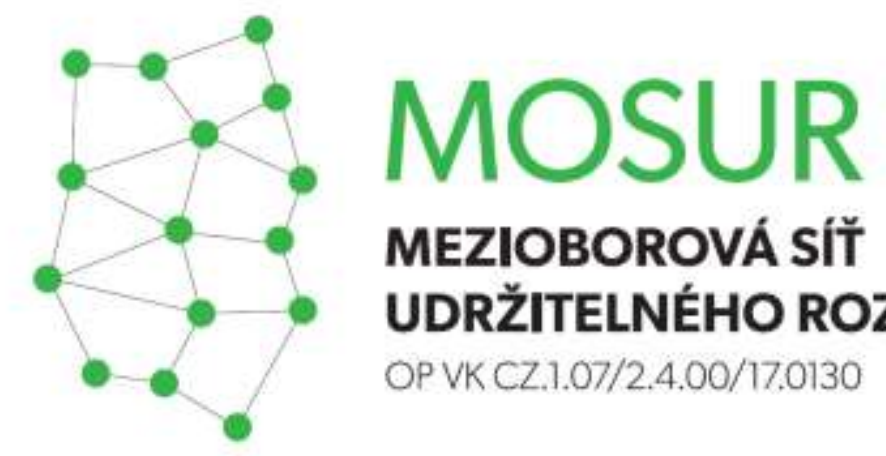

\section{MEZIOBOROVÁ SÍT} UDRŽITELNÉHO ROZVOJE

OP VK CZ.1.07/2.4.00/17.0130
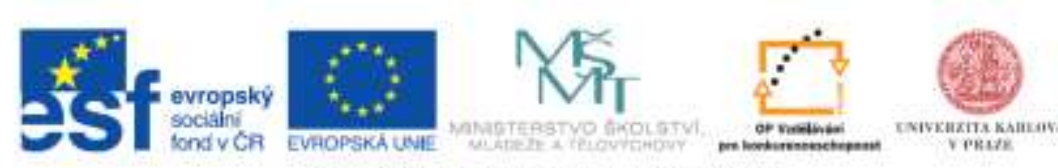

INVESTICE DO ROZVOUE VZDELAVANI 